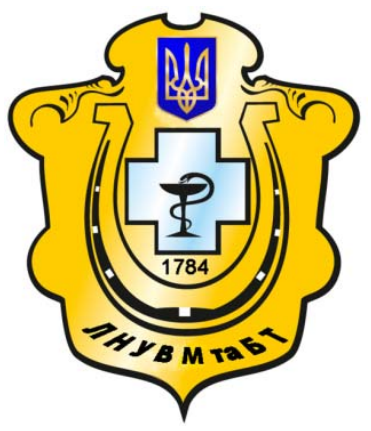

Науковий вісник Львівського національного університету ветеринарної медицини та біотехнологій імені С.3. Гжицького

Scientific Messenger of Lviv National University of Veterinary Medicine and Biotechnologies named after S.Z. Gzhytskyj

doi:10.15421/nvlvet6608

ISSN 2413-5550 print

ISSN 2518-1327 online

$\underline{\text { http://nvlvet.com.ua/ }}$

UDC 616 - 092.9: 615.3

\title{
Therapeutic effectiveness of the drug RBS - DOG as immune modulating means in the treatment of dogs with wounds at hypo ergic type of inflammation
}

\author{
M.B. Gajduk, B.V. Gutyj, D.F. Gufrij \\ bvh@ukr.net \\ Lviv National University of Veterinary Medicine and Biotechnologies named after S.Z. Gzhytskyi, \\ Pekarska Str., 50, Lviv, 79010, Ukraine
}

The article deals with the results of searches on the therapeutic effectiveness of RBS - DOG (Manufacturer PP «Laboratory Erbis» at Ltd. «Erbis» Kyiv, Ukraine) as immune modulating means in the complex treatment of open mechanical damage in dogs with hypo ergic type of inflammation. The effectiveness of treatment was assessed by clinical condition, speeds wound healing, and also by the results of laboratory tests on blood by morphological and biochemical parameters. It was established that more active recovery of clinical status, wound healing and normalization of dogs blood indices was in the experimental group when using in the complex treatment of preparation $R B S-D O G$.

Thus, the combined treatment of dogs with purulent wounds using immune stimulating preparation «Erbisol» and a solution of aqua chelates nanoclusters Argentum and Cuprum along with the acceleration of wound healing leads to a rapid normalization of the morphological structure of blood, compared with the traditional method of treatment.

The additional use of the preparation RBS - DOG in doses and by the scheme provided for postcard-tab, improved clinical status, accelerated wound healing, increased immunity, and speed up the recovery of animals compared to animals that did not receive the drug.

In addition to the therapeutic effect, the preparation RBS - DOG was well tolerated target by animals and caused no side effects.

Key words: preparation "RBS - DOG», purulent wounds, hypo ergic type of inflammation, therapeutic effectiveness, dogs.

\section{Терапевтична ефективність препарату РБС-ДОГ в якості імуномодулюючого засобу при лікуванні собак з ранами при гіпоергічному типі запалення}

\author{
М.Б. Гайдюк, Б.В. Гутий, Д.Ф. Гуфрій \\ bvh@ukr.net
}

\begin{abstract}
Львівський начіональний університет ветеринарної медицини та біотехнологій імені С.З. Гюсицького, вул. Пекарська, 50, м. Львів, 79010, Украӥна
\end{abstract}

У статті описано результати досліджень щодо терапевтичної ефективності препарату РБС-ДОГ (виробник ПП «Лабораторія Ербіс» на ТОВ «Ербіс», м. Київ, Україна) як імуномодулюючого засобу при комплексній терапї̈ відкритих механічних пошкоджень у собак з гіпоергічним типом запалення. Ефективність лікування оцінювали за клінічним станом, швидкістю загоєння ран, а також за результатами лабораторних досліджень крові за морфологічними та біохімічними показниками. Встановлено, щьо у дослідній групі відбувалося більш активне відновлення клінічного стану, загоєння ран та нормалізація показників крові собак при застосуванні у комплексній терапії препарату РБС-ДОГ.

Комплексне лікування собак з гнійними ранами із застосуванням імуностимулювального препарату «Ербісол» та розчину нанокластерів аквахелатів Артентуму та Купруму поряд із прискоренням загоєння ран призводить до швидкоі нормалізації морфологічного складу крові порівняно із традиційним методом лікування.

Citation:

Gajduk, M.B., Gutyj, B.V., Gufrij, D.F. (2016). Therapeutic effectiveness of the drug RBS - DOG as immune modulating means in the treatment of dogs with wounds at hypo ergic type of inflammation. Scientific Messenger LNUVMBT named after S.Z. Gzhytskyj, 18, 2(66), 35-39. 
Додаткове застосування препарату РБС-ДОГ у дозах та за схемою, передбаченою листівкою-вкладкою, покрашувало клінічний стан, прискорювало загоєння ран, підвищувало імунітет, чим пришвидшувало одужання тварин, у порівнянні з тваринами, які не отримували даний препарат. Крім терапевтичного ефекту, препарат РБС-ДОГ добре переносився иільовими тваринами та не викликав побічної дї

Ключові слова: препарат «РБС-ДОГ», гнійні рани, гіпоергічний тип запалення, терапевтична ефективність, собаки.

\title{
Терапевтическая эффективность препарата РБС-ДОГ в качестве иммуномодулирующего средства при лечении собак с ранами при гипоэргическом типе воспаления
}

\author{
М.Б. Гайдюк, Б.В. Гутый, Д.Ф. Гуфрий \\ bvh@ukr.net
}

\begin{abstract}
Львовский национальный университет ветеринарной медицины и биотехнологий имени С.3. Гжицкого, ул. Пекарская, 50, г. Львов, 79010, Украина
\end{abstract}

\begin{abstract}
В статье описаны результаты исследований по терапевтической эффективности препарата РБС-ДОГ (производитель ООО «Лаборатория Эрбис» на ООО «Эрбис», г. Киев, Украина) в качестве иммуномодулирующего средства при комплексной терапии открытых механических повреждений у собак с гипоэргическим типом воспаления. Эффективность лечения оценивали за клиническим состоянием, скоростью заживления ран, а также по результатам лабораторных исследований крови по морфологическим и биохимическим показателям. Установлено, что в опытной группе происходило более активное восстановление клинического состояния, заживление ран и нормализация показателей крови собак при применении в комплексной терапии препарата РБС-ДОГ.

Комплексное лечение собак с гнойными ранами с применением иммуностимулирующего препарата «Эрбисол» и раствора нанокластеров аквахелатов серебра и меди наряду с ускорением заживления ран приводит к быстрой нормализации морфологического состава крови по сравнению с традиичонным методом лечения.

Дополнительное применение препарата РБС-ДОГ в дозах и по схеме, предусмотренной открыткой-вкладышем, улучшало клиническое состояние, ускоряло заживление ран, повышало иммунитет, чем ускоряло выздоровление животных, по сравнению с животными, которые не получали этот препарат. Кроме терапевтического эффекта, препарат РБС-ДОГ хорошо переносился целевыми животными и не вызывал побочных эффектов
\end{abstract}

Ключевые слова: препарат «РБС-ДОГ», гнойные раны, гипоэргический тип воспаления, терапевтическая эффективность, собаки.

\section{Introduction}

In recent years, interest of scientists and practical experts of veterinary medicine to the problem of immune modulation has significantly increased, which is associated primarily with increasing load on the animal organism anthropogenic factors, a substantial growth immune deficiencies and understanding that the development of most of pathological processes is caused by dysfunction of the immune system (Borysevych et al., 2010; Khariv et al., 2016; Martyshuk et al., 2016). In addition, the process of wound healing involved interrelated biological processes that occur not only locally, but cover the whole body (Gajdjuk and Homyn, 2010). That is why, it is necessary to take into account the general state of animals, as in the pathogenesis of purulent inflammation processes are also immunosuppressive mechanisms of action which leads to immunodeficiency state, which complicates the disease. In this regard, depth study is promising due to the influence of immune modulator RBS - Dog for the treatment of dogs with wounds at hypo ergic type of inflammation. The preparation is a complex of natural nonprotein low molecular organic compounds of nonhormonal origin derived from embryonic tissues of animals (Gajdjuk and Homyn, 2010).

Treatment of dogs with purulent wounds were conducted using a new method of immune stimulating preparation RBS - DOG in combination with other drugs, these animals were attributed to the experimental group. Con- trol over these conditions served as animals whose treatment was performed with the help of traditional method.

The purpose of research is to investigate the therapeutic effectiveness of the preparation RBS - DOG for dogs treatment of wounds with hypo ergic type of inflammation.

\section{Materials and methods}

Clinical researches of therapeutic efficacy of RBS DOG preparation were performed on dogs of the private sector aged $3-6$ years in 6 clinics of Lviv region and the city of Lviv. In particular, in the Lviv regional and urban state veterinary hospitals, state veterinary hospital of Chervonograd and Sokalj, a military unit 2418 of Western Regional Department of State Border Service of Ukraine, dog training center and also in clinic of small animal at surgery department of LNUVM and BT named after S.Z. Gzhytskyj. It was created two groups of animals: control $(n=5)$ and experimental $(n=5)$.

For the functional state of sick animals organism it was conducted surveillance during the treatment period. It was done clinical, plan metric, hematological and immunological research. Blood were taken from the lateral saphenous vein of forelimb before the experiment and the third, fifth and tenth day after the start of treatment. Blood was stabilized with heparin (20 units per $1 \mathrm{ml}$ of blood). Laboratory tests were conducted in the laboratory of clinical and biological research GNIKI Veterinary medicines 
and dietary supplements as well as in laboratories veterinary clinics.

Morph functional state of animals organism before and at the third, fifth and tenth day after the beginning of treatment was established by morphological and biochemical indices of blood, which are determined in accordance with generally accepted methods.

In stabilized blood morphological parameters were investigated: the number of red blood cells, white blood cells, leucogram, hematocrit, erythrocyte sedimentation rate (ESR). The content of hemoglobin in the blood was determined with the help of nephelometric hemoglobin cyanide method. The total number of white blood cells and red blood cells was investigated in Gorjaeva chamber, leukocytar formula was deduced based on microscopy of blood smears and differential counting of different forms of leukocytes.

Serum samples were tested for total protein, the activity of ALT, AST, alkaline phosphatase, creatinine content, urea using semi-automatic biochemical analyzer (HumaLyzer 3000) (Kocjumbas et al., 2006; Levchenko et al., 2010). The data were treated statistically.

\section{Results and discussion}

Sick animals were admitted to the clinic with symptoms: general condition was suppressed, the body temperature was $37.2-38.7^{\circ} \mathrm{C}$, pulse rate $114-131$ beats per minute, respiratory $-27-38$ times per minute. The bor- der of the wound were inactive, painful and swollen, the surface was covered with thick layer of mucoid, thick exudate of white and gray colour. The diagnosis was done on the basis of clinical signs and laboratory searches of sick animals blood. In addition to specific treatment, the 1st group of animals (research) received an additional preparation RBS - DOG, as intramuscular or intravenous injection, the dogs up to $10 \mathrm{~kg}-1 \mathrm{ml}$, dogs over $10 \mathrm{~kg}-$ $2 \mathrm{ml}$ for 5 days once a day. Animals of the $2^{\text {nd }}$ group were given a similar treatment without the preparation RBS DOG.

According to data of laboratory searches of dogs blood, obtained before the treatment it was found reducing the number of red blood cells in 1.3-2.0 times that is connected to the general state of animals organism. The number of leukocytes exceeded the upper limit that is connected with inflammatory processes that occur in the wound. This is also confirmed by changes in leukocyte formula, according to which the percentage content of nuclear coli of neutrophils was on average 7.5 times higher than the norm. The number of lymphocytes was lower in 1.1-2.1 times lower than normal, testified the decline in activity link of antivirus protection.

Thus, the combined treatment of dogs with purulent wounds using immune stimulatory preparation RBS DOG along with the acceleration of wound healing leads to rapid morphological normalization of the blood compared to the traditional method of treatment.

Table 1

The morphological structure of blood when using immune stimulatory preparation RBS - DOG for the treatment of purulent wounds in dogs with hypo ergic type of inflammation $(M \pm m, n=5)$

\begin{tabular}{|c|c|c|c|c|}
\hline Indexes & $\begin{array}{l}\text { Groups of } \\
\text { animals }\end{array}$ & Before treatment & $10^{\text {th }}$ day & Clinically healthy animals \\
\hline Hemoglobin (g/l) & $\begin{array}{c}\text { I } \\
\text { II }\end{array}$ & $122.4 \pm 2.2$ & $\begin{array}{c}138.8 \pm 2.4 * * \\
133.2 \pm 3.7\end{array}$ & $120-180$ \\
\hline Erythrocytes (t/l) & $\begin{array}{l}\text { I } \\
\text { II }\end{array}$ & $4.1 \pm 0.1$ & $\begin{array}{c}4.8 \pm 0.2 * * \\
4.4 \pm 0.2\end{array}$ & $5.5-8.4$ \\
\hline Thrombocytes (d/1) & $\begin{array}{c}\text { I } \\
\text { II }\end{array}$ & $344.0 \pm 28.8$ & $\begin{array}{c}414.0 \pm 54.0 * \\
360.0 \pm 38.5\end{array}$ & $180-320$ \\
\hline Leucocytes (g/l) & $\begin{array}{l}\text { I } \\
\text { II }\end{array}$ & $17.9 \pm 0.8$ & $\begin{array}{c}8.3 \pm 2.7 * * * \\
9,7 \pm 1,2\end{array}$ & $8.5-10$ \\
\hline Eosinophils, \% & $\begin{array}{l}\text { I } \\
\text { II }\end{array}$ & $0.2 \pm 0.1 * *$ & $\begin{array}{c}0.7 \pm 0.1 * * \\
0.5 \pm 0.2 *\end{array}$ & $2-10$ \\
\hline $\begin{array}{l}\text { Nuclear coli of neutrophils, } \\
\%\end{array}$ & $\begin{array}{l}\text { I } \\
\text { II }\end{array}$ & $12.4 \pm 0.5$ & $\begin{array}{c}5.6 \pm 0.2 \\
6.8 \pm 0.4^{*}\end{array}$ & $1-6$ \\
\hline Segmented neutrophils, $\%$ & $\begin{array}{l}\text { I } \\
\text { II }\end{array}$ & $48.1 \pm 0.6$ & $\begin{array}{c}49.8 \pm 0.6 \\
44.5 \pm 0.8^{*}\end{array}$ & $43-72$ \\
\hline Lymphocytes, \% & $\begin{array}{l}\text { I } \\
\text { II }\end{array}$ & $35.8 \pm 0.9$ & $\begin{array}{c}34.9 \pm 0.7 \\
42.0 \pm 0.92 *\end{array}$ & $21-40$ \\
\hline Monocytes, \% & $\begin{array}{l}\text { I } \\
\text { II }\end{array}$ & $0.7 \pm 0.3$ & $\begin{array}{c}2.1 \pm 0.2 \\
2.9 \pm 0.3^{*}\end{array}$ & $3-10$ \\
\hline
\end{tabular}

There were also significant $(\mathrm{p}<0.05)$ reduction in the percentage of young and nuclear coli of neutrophils compared with the index before the treatment of animals in the experimental group $41.9 \%$ and $28.2 \%$, respectively, while in the control group this reduction was $12.9 \%$ and $29.0 \%$, respectively.

On the 10th day of treatment hemoglobin continue growing relatively to the indicator before treatment to $11.8 \%(\mathrm{p}<0.01)$. In the control group the level of hemoglobin has also increased as compared to the values at the beginning of the treatment by $8.1 \%$, however, has not reached the level of clinically healthy dogs, remaining lower than $2.7 \%$. Number of red blood cells in the experimental group increased in 1.2 times relatively to terms before treatment, while in the control group, their number has increased to 1.07 times, respectively. At the same time on the $10^{\text {th }}$ day of search the number of leukocytes has decreased further compared with the index at the beginning of treatment in the experimental group at $48.6 \%$ and $10.2 \%$ in the control while remaining within 
the physiological norm. Number segmented neutrophils experienced growth in both groups, at $3.5 \%$ and $0.6 \%$ in the experimental and control groups, respectively.

The percentage of lymphocytes did not change in the experimental group and in the control has decreased compared to the indicator before treatment of almost $7 \%$. At the same time the number of monocytes in the experimental group increased in 3.1 times, exceeding the value in clinically healthy dogs by $37.5 \%$, and in control, this increase was 4.4 times and about 2 times comparatively values of healthy dogs. The number of eosinophils on the $10^{\text {th }}$ day of treatment significantly increased in animals in both groups compared with the indices before treatment, but remained lower than normal.

At 10th day, the number of young neutrophiles in the blood of dogs from experimental group was 4.4 times lower than before treatment and closer to the value of the norm. At the same time in the control group, their number has decreased by 2.8 times remain under these conditions for more indicators of healthy dogs by $36.4 \%$.

The percentage of coli nuclear neutrophils has also suffered a reduction in animal from the research group at $54.8 \%$ compared to the indices before the treatment remaining under these conditions, higher by $14.3 \%$ to the values of healthy dogs, while in the control group of animals, their number has decreased comparatively to the importance before the treatment by $45.2 \%$, but to the standard values did not return, remaining higher at $29.4 \%$.

The level of segmented neutrophils in animal from the experimental group has increased compared with the rate before treatment to $3.4 \%$, being lower by $8.5 \%$ compared to the values of healthy dogs, whereas in the control group, their number significantly $(\mathrm{p}<0.05)$ decreased compared with those before treatment to $7.5 \%$, being $18.2 \%$ lower comparatively clinically healthy dogs. The number of lymphocytes in the experimental group of animals experienced a further increase, increasing rela- tively to the indicator before the treatment by $17.3 \%$ not reaching under these conditions the significance of clinically healthy dogs at $12 \%$. In the control group, the percentage of lymphocytes were not significantly different from the previous day of the research almost returned to indicator of healthy animals.

A similar was the number of monocytes dynamic, which increased in the experimental group comparatively values of healthy dogs by $23.8 \%$ and in the control group to $44.8 \%$.

Thus, the combined treatment of dogs with purulent wounds using immune stimulating preparation «Erbisol» and a solution of aqua chelates nanoclusters Argentum and Cuprum along with the acceleration of wound healing leads to a rapid normalization of the morphological structure of blood, compared with the traditional method of treatment. Biochemical parameters of dogs blood before treatment show the decrease in serum total protein (table 2 ), that is connected with decrease in revenues protein due to inhibition of animals and loss of appetite.

We observed also the increased activity of enzymes transamination. In particular the increase of ALT and AST indicate the damage to the membranes of muscle fibers at purulent necrotic processes and output of ALT into the bloodstream. Increasing the concentration of urea pointed to the intoxication of the body with decay products of necrotic tissue.

On the 10th day of treatment, it was found decreased activity of AST in animals from the $1^{\text {st }}$ group by 1.4 times and the $2^{\text {nd }}$ group by 1,8 times, ALT -1.7 and 1.5 times, respectively (table 2), compared with those before treatment. The normalization of transaminase enzyme activity pointed to the restoration of reparative processes in the body.

So, for the treatment of dogs with purulent wounds with hypo ergic type of inflammation is path genetically justified the use of immune stimulating agents.

Table 2

Biochemical parameters of blood in the application of immunostimulating preparation RBS - DOG for treatment of purulent wounds in dogs with inflammation hypo ergic type of inflammation $(M \pm \mathbf{m}, \mathbf{n}=\mathbf{5})$

\begin{tabular}{|l|c|c|c|c|}
\hline \multicolumn{1}{|c|}{$\begin{array}{l}\text { Indexes } \\
\text { Total protein }\end{array}$} & $\begin{array}{c}\text { Groups of } \\
\text { animals }\end{array}$ & Before treatment & $10^{\text {th }}$ day & Clinically healthy animals \\
& I & $57.6 \pm 4.1$ & $62.3 \pm 2.7^{*}$ & $60-75$ \\
\hline Urea & II & $56.8 \pm 3.5$ & $5.9 \pm 0.9$ & $8.1 \pm 1.3$ \\
& II & $8.9 \pm 0.7$ & $78.5 \pm 7.4^{*}$ & $82.3 \pm 9.1$ \\
\hline ALT & I & $10.1 \pm 0.5$ & $121.3 \pm 8.4^{*}$ & $99.7 \pm 5.3$ \\
\hline AST & II & $128.5 \pm 7.9$ & $78.4 \pm 7.5^{*}$ \\
\hline ALP & II & $165.1 \pm 17.1$ & $73.2 \pm 18.4^{*}$ & $11-42$ \\
\hline
\end{tabular}

\section{Conclusions}

1. In accordance with research results of a clinical trial of immune stimulating preparation RBS - DOG, the production of PE «Erbis Laboratory» at Ltd. «Erbis» Kyiv, Ukraine, it was found its therapeutic efficacy in the complex treatment of dogs with wounds at hypo ergic type of inflammation. The additional use of the preparation RBS DOG in doses and by the scheme provided for postcard- tab, improved clinical status, accelerated wound healing, increased immunity, and speed up the recovery of animals compared to animals that did not receive the drug.

2 . In addition to the therapeutic effect, the preparation RBS - DOG was well tolerated target by animals and caused no side effects. 


\section{References}

Gajdjuk, M.B., Homyn, N.M. (2010). Obg'runtuvannja docil'-nosti zastosuvannja erbisolu za gnijnyh zapal'nyh procesiv u sobak. Naukovyj visnyk vet. medycyny - Bila Cerkva. 4(76), 35-37 (in Ukrainian).

Borysevych, V.B., Kaplunenko, V.G., Kosinov, M.V. (2010). Nanomaterialy V biologii'. Osnovy nanoveterynarii': navch. i prakt. Posibnyk. K.: VD «Avicena» (in Ukrainian).

Levchenko, V.I., Golovaha, V.I., Kondrahin, I.P. (2010). Metody laboratornoi' klinichnoi' diagnostyky hvorob tvaryn. K.: Agrarna osvita (in Ukrainian).
Khariv, M., Gutyj, B., Butsyak, V., Khariv, I. (2016). Hematological indices of rat organisms under conditions of oxidative stress and liposomal preparation action. Biological Bulletin of Bogdan Chmelnitskiy Melitopol State Pedagogical University. 6(1), 276-289.

Kocjumbas, I.Ja., Malyk, O.G., Peterega, I.P. (2006). Doklinichni doslidzhennja veterynarnyh likars'kyh zasobiv. L'viv: Triada pljus (in Ukrainian).

Martyshuk, T.V., Gutyj, B.V., Vishchur, O.I. (2016). Level of lipid peroxidation products in the blood of rats under the influence of oxidative stress and under the action of liposomal preparation of «Butaselmevit», Biological Bulletin of Bogdan Chmelnitskiy Melitopol State Pedagogical University. 6(2), 22-27.

Стаття надійшла до редакиії 13.09.2016 